\title{
PENDIDIKAN ANAK DINI USIA (PADU) DALAM ISLAM: Sebuah Analisis Gender
}

\author{
Agus Purnomo \\ Dosen STAIN Ponorogo \\ Peserta Program Doktor IAIN "Sunan Ampel" Surabaya
}

\begin{abstract}
ABSTRAK
Pendidikan anak merupakan kewajiban bersama seorang ayah dan ibu. Kepribadian anak yang seimbang akan tercapai jika semua potensi dirinya dikembangkan secara maksimal, tidak saja pada intelektuaitas tetapi uga pada aspek emosionalitas dan spiritualitasnya. Pendidikan anak sejak dini usia (PADU), merupakan upaya penting dalam menentukan proses perkembangan pribadi anak untuk mencapai kematangan dan kedewasaan. Peran bersama ayah dan ibu dalam mendidik anak, juga turut memperngaruhi bangunan profil mereka dengan "meramu" kepribadian orangtuanya. Karena itu pula, diperlukan role model pendidikan yang baik, yang harus diteladankan, dibiasakan dan dilatihkan oleh kedua orang tua kepada anak-anaknya dalam keluarga. Melalui PADU pulalah, "kemerdekaan" anak bisa mulai diapresiasi dan dikembangkan.
\end{abstract}

\section{A. Pendahuluan}

Anak yang tumbuh dan berkembang sejak dalam kandungan hingga meninggal, mengalami proses tahap demi tahap. Untuk itu, upaya membina dan mengembangkan pribadi anak yang terdiri dari aspek jasmaniah dan rohaniahnya melalui pendidikan juga harus dilaksanakan secara bertahap. Karena hanya dengan pendidikan, kemampuan, kematangan dan kesempurnaan pribadi anak akan dicapainya. ${ }^{1}$

Tujuan akhir pendidikan Islam yang berupaya mewujudkan pribadi muslim yang sempurna (kamil), yang bisa mengemban fungsinya sebagai 'abid dan khalifah, ${ }^{2}$ secara ideal harus telah dilaksanakan tidak saja ketika anak telah

\footnotetext{
${ }^{1}$ M. Arifin, Filsafat Pendidikan Islam (Jakarta: Bumi Aksara, 2000), 11.

${ }^{2}$ Abuddin Nata, Filafat Pendidikan Islam (Jakarta: Logos, 1997), 41.
} 
lahir, tetapi pada saat pre-natalpun anak juga harus mendapatkan pendidikan. ${ }^{3}$ yang memandang tahap ini sebagai al-janin, yakni tingkat anak yang berada dalam kandungan dan adanya kehidupan setelah ditiupkannya roh Allah (wanafakhtu fihi min ruhi) pada usia empat bulan, merupakan tahapan pertama pendidikan pre-natal.

Pendidikan pre-natal, sesungguhnya tidak saja dimulai ketika anak berada dalam kandungan, tetapi sejak konsepsi, yakni sejak bertemunya sel sperma ayah (suami) dengan sel telur ibu (isteri). Bahkan juga ada beberapa pendapat yang mengatakan bahwa pendidkan anak sebenarnya telah dimulai sejak masa prakonsepsi, yakni sebelum seorang laki-laki memilih seorang perempuan untuk dijadikan sebagai isterinya. Beberapa isyarat dalam hadits nabi misalnya: "seorang perempuan dinikahi karena empat hal: hartanya, kecantikannya, nasabnya dan agamanya. Tetapi agama diisyaratkan untuk dipilih menjadi pertimbangan pertama karena hanya kepada agama, bangunan keluarga didasarkan". Idealnya adalah semua unsur dimaksud dalam hadits tersebut terpenuhi, yakni aspek ekonomi, performa fisik, genealogi dan moralitasnya. Namun kenyataannya di dunia ini tidak ada manusia yang sempurna, sehingga pertimbangan agama yang harus menjadi pilihan pertama yang dianjurkan oleh Islam kendati disebut terakhir menemukan relevansinya.

Dalam konteks hadits tersebut, kendati disebutkan bahwa seolah seorang perepuan merupakan obyek yang dipilih, namun sesungguhnya jika kita kembalikan kepada prinsip perkawinan sebagai ikatan yang kokoh atas dua insan

${ }^{3}$ Zainuddin, dkk. Seluk-beluk Pendidikan dari al-Ghazali. (Jakarta: Bumi Aksara, 1991), 69. 
dan saling mempergauli dengan penuh kebaikan (mu'asyarah bi al-ma'rif), maka sebenarnya perempuan juga memiliki hak, tidak untuk sekedar menerima atau menolak, tetapi juga memilih calon pendampingnya. Hal ini karena tercapainya tujuan perkawinan yakni terciptanya keluarga harmonis, yakni keluarga yang sakinah, mawaddah wa rahmah hanya akan terealisir ketika keluarga tersebut dibangun dengan basis pada cinta kasih, saling pengertian, saling mendukung, serta menghindari praktik-praktik kekerasan. Hanya dalam keluarga yang harmonis pulalah, anak juga akan bisa tumbuh kembang secara maksimal semua potensi dirinya.

\section{B. Mendidik Anak sebagai Kewajiban Bersama Ayah dan Ibu}

Kendati seorang ibu memiliki peran sentral dalam mendidik anak, namun sebenarnya pendidikan anak merupakan kewajiban bersama, bahkan menjadi tanggung jawab yang lebih bagi seorang ayah. Hal ini misalnya dapat dilihat pada ketentuan al-Qur'an misalnya dalam QS. Luqman: 13-14, bahwa kewajiban mendidik anak, mengajari mereka tentang akidah, ibadah dan moralitas juga merupakan tanggung jawab seorang bapak.

"Dan ingatlah ketika Luqman berkata kepada anaknya, di waktu ia memberi pelajaran kepadanya; "Hai anakku, janganlah kamu mempersekutukan Allah, sesungguhnya memperksekutukan Allah adalah benar-benar kedzaliman yang besar". 4

Dalam ayat selanjutnya, dijelaskan bagaimana moralitas anak juga dibangun oleh orang tua, yakni bagaimana anak berakhlak kepada kedua orangtuanya, terutama kepada ibunya yang telah mengandung dan melahirkannya, dengan

${ }^{4}$ QS. Luqman (31): 13. 
bahasa dan ungkapan yang bahkan demikian menjunjung tinggi harkat perempuan sebagai seorang ibu, berikut:

"Dan Kami perintahkan kepada manusia (berbuat baik) kepada kedua orantyanya, ibunya telah mengandungnya dalam keadaaan lemah yang bertambah-tambah, dan menyapihnya dalam dua tahun. Bersyukurlah kepada-Ku dan kepada kedua orang ibu bapakmu, hanya kepada-Ku lah kembalimu." 5

Di antara fungsi keluarga bagi tumbuh kembang anak adalah fungsi protektif, religius dan edukatif. Keluarga adalah tempat yang paling aman dan nyaman bagi seluruh anggota keluargaya. Dalam hal ini, Nabi Muhammad SAW bersabda bahwa: "rumahku adalah surgaku" (bayti jannati). Surga tidak tercipta hanya karena kemewahan dan keindahan ornamentasi rumah, namun sebaliknya surga akan terbangun jika di dalam rumah penuh dengan kehangatan yang melindungi semua anggota keluarga, keamanan yang menentramkan anggotanya, dan pendidikan agama yang membuat seluruh anggotanya memiliki tingkat kepatuhan dan ketaatan serta komitmen keagamaan yang tinggi terhadap Tuhan.

Terdapat banyak perintah, baik dalam al-Qur'an maupun al-Hadits tentang peran ibu dalam posisinya sebagai tokoh sentral dalam mewujudkan generasi penerus yang berkualitas. Bahkan di dalam sebuh hadits disebutkan bahwa seorang ibu memiliki derajat lebih tinggi dibanding seorang ayah dalam persoalan kewajiban anak dalam menghormati orang tuanya. Hal ini karena, seorang ibu adalah induk sekolah (umm al-madrasah). Dalam konteks ini seorang ibu memiliki peran sentral dalam menciptakan generasi penerus yang berkualitas. Peran tersebut telah diambil dan dimainkannya sejak ia mengandung, melahirkan,

\footnotetext{
${ }^{5}$ QS. Luqman (31): 14
} 
menyusui, merawat dan mengasuhnya sejak bayi, anak-anak, remaja, bahkan hingga dewasa. Karena peran ini pulalah, maka keluarga disebut sebagai basis pendidikan pertama dan utama bagi anak.

Untuk menunjang peran ibu sebagai induk sekolah (al-mar'ah hiya umm al-madrasah), terdapat hadits yang memerintahkan seorang laki-laki agar memilih calon pendamping hidup yang memiliki (potensi) banyak anak dan banyak cinya (inkah al-walud wa al-wadud). Hadits ini sejalan dengan tujuan hakiki pernikahan yakni untuk mendapatka kebahagiaan lahir dan batin dalam naungan cinta dan keridhaan Allah, yang diderivasi antara lain dengan tujuan memiliki keturunan yang shaleh (lithalab al-dzurriyat al-hasanah). Demikian juga, al-wadud, karena dengan cinta bangunan keluarga bisa kokoh. Kata wadud, mawaddah, tersusun dari huruf m-w-d-d yang berarti kelapangan dan kekosongan., yang berarti bahwa mawaddah adalah kelapangan dan kekosongan hati dari kehendak buruk. Memang mawaddah bukan berarti tanpa masalah, namun mawaddah tidak sampai memutuskan hubungan seperti yang terjadi pada dua orang yang bercinta. Mawaddah adalah cinta plus, karena hatinya selalu lapang dan kosong dari keburukan (menerima kebaikan sekaligus keburukan suami-istrinya).

Dalam kondisi seperti itu, maka akan tercipta hubungan suami-isteri yang harmonis, sehingga konsepsi (pertemuan sel sperma dan sel telur juga bisa dilakukan dengan baik, dalam kondisi penuh kebahagiaan), yang hal ini tentunya juga akan sangat berpengaruh bagi pertumbuhan janin kelak. Proses konsepsi yang dilakukan dengan penuh kebahagiaan, dengan membaca bacaan-bacaan tertentu, diharapkan juga akan mendapatkan keturunan yang baik. Demikian juga 
ketika seorang isteri melaksanakan tugas kodratinya, yakni hamil, suami juga memiliki tugas non-kodrati, berupa kewajiban menyiapkan dan memenuhi kebutuhan lahir-batin yang bisa mendukung kehamilan isteri. Kehamilan yang baik dan sehat tentunya juga akan melahirkan generasi yang sehat. Oleh karena itu, Islam memberikan beberapa tuntunan yang dianjurkan untuk dilakukan oleh pasangan suami isteri yang sedang menunggu kehadiran seorang bayi, dengan memperbanyak ibadah dan amal shaleh.

Di saat kelahirannya, nabi memerintahkan agar seorang ayah memperdengarkan adzan di telinga kanan dan iqamat di telinga kiri anak (HR Abu Ya'la dari Husein ib Ali). Hal ini, sesungguhnya merupakan sarana bagi orang tua untuk mengembangkan fitrah keberagamaan yang dimiliki anak sejak dalam kandungan. Sebagaimana diisyaratkan dalam QS. 7: 172 bahwa telah terjadi perjanjian primordial antara manusia/janin dengan Tuhan agar manusia mengakui bahwa Allah adalah Tuhan mereka. Pendidikan yang dilakukan sejak anak usia dini, tidak dilakukan untuk mengekang dan menekan fitrah anak, ${ }^{6}$ tetapi justru diarahkan untuk mengembangkan potensi positif (QS.30:30), meski pada diri anak terdapat juga kecenderungan berperilaku buruk sebagaimana digambarkan dalam QS. 91:7-8. Namun karena dalam diri manusia terdapat ruh Tuhan (QS.31:9), maka mendominasikan potensi positif pada dasarnya lebih mudah karena bersesuaian dengan fitrah anak yang hanif (condong kepada kebenaran), ketimbang mendominaskan potensi negatif yang justru bertentangan dengan fitrahnya yang hanif tersebut. Dengan adanya ruh Tuhan dalam diri manusia,

${ }^{6}$ M. Athiyah Al-Abrasyi,. Dasar-dasar Pokok Pendidikan Islam (Jakarta: Bulan Bintang, 1987), 23. 
berarti bahwa manusia, baik laki-laki maupun perempuan memiliki dimensi ilahiyah (lahut) yang sama, yang menurut Hasan Langgulung hal tersebut mengandung makna bahwa Tuhan memberi manusia (tanpa membedakan jenis kelaminnya) potensi yang sejalan dengan sifat-sifat-Nya yang harus diejawantahkan dalam kehidupannya, yang hal ini dilatihkan melalui proses pendidikan sejak anak usia dini. ${ }^{7}$

Proses pendidikan sejak usia dini ini, dalam Islam juga tidak dibedakan aspek mana yang harus didahulukan bagi anak laki-laki maupun anak perempuan, karena pembentukan kepribadian melalui pendidikan ini diarahkan untuk membentuk pribadi yang memiliki akhlak yang mulia, di mana tingkat kemuliaan akhlak ini berkait erat dengan tingkat keimanan. ${ }^{8}$ Hal ini sejalan dengan hadits nabi: “Orang mukmin yang paling sempurna imannya adalah orang mu'min yang paling baik akhlak-nya"( HR al-Tirmidzy).

\section{Kesetaraan Potensi dan Peran Edukatif Laki-laki dan Perempuan}

Di dalam al-Qur'an diillustrasikan bahwa laki-laki dan perempuan adalah sama-sama bagian dari bangsa manusia yang satu (QS. Al-baqarah: 2130 dan sebagai keturunan Adam digambarkan menjadi orang-orang yang dimuliakan oleh Allah SWT (QS. Al-Isra: 70). Dengan demikian, laki-laki dan perempuan adalah dua jenis mahluk yang setara, yang parameternya hanya kreativitas dan amal positif serta ketaqwaannya kepada Allah (QS. Al-Hujurat: 13).

Al-Qur'an mengungkapkan perbedaan mendasar antara laki-laki dan perempuan, tetapi harus dicermati apakah ungkapan tersebut mengacu kepada

\footnotetext{
${ }^{7}$ Jalaluddin dan Said, Usman. Filsafat Pendidikan Islam (Jakarta: Rajagrafindo Persada, 1994), 17.

${ }^{8}$ Hasan Langgulung, Beberapa Pemikiran tentang Pendidikan Islam (Bandung: Al-Maarif, 1980), 41 .
} 
unsur biologis, unsur budaya atau keduanya sekaligus. Seringkali ayat-ayat alQur'an yang menunjukkan kekhususan-kekhususan perempuan seperti menstruasi, menopause, hamil dan sebagainya, disalahpahami dan dijadikan alat untuk memojokkan perempuan pada sektor domestik. Ironisnya, ayat-ayat tersebut sering diasosiasikan dengan ayat lain yang menyatakan bahwa laki-laki mempunyai satu tingkat kelebihan di atas kaum perempuan (QS.2:228) dan ayat yang menyatakan bahwa kaum laki-laki itu pemimpin bagi kaum perempuan (QS.4:34). Padahal al-Qur'an tidak pernah mengungkapkan bahwa fungsi reproduksi kaum perempuan menjadi sebab atau alasan yang menjadikannya mahluk subordinate (the second sex).

Terdapat dua aspek penting yang harus ditanamkan kepada anak-anak dini usia, baik laki-laki maupun perempuan, yakni aspek iman dan akhlak. Oleh karena itu, beberapa isyarat dan petunjuk tentang pendidikan anak sebagaimana yang dikisahkan dalam al-Qur'an (QS. 31: 13), bahwa yang petama kali diajarkan adalah tauhid (mengenal Tuhan) disusul kemudian dengan pendidikan akhlaq (QS. 31:14-17) menemukan relevansinya dengan potensi yang dimiliki anak. Demikian juga nabi Muhammad sendiri ketika pertama kali mendidik umatnya juga menekankan aspek akidah baru disusul akhlak. ${ }^{9}$

Dengan pembiasaan yang baik sejak anak usia dini, akan sangat mempengaruhi dan bahkan membentuk pribadi muslim sebagaimana dicitakan oleh Islam. Dalam konteks inilah, maka orang tua berkewajiban untuk menggali dan mengembangkan potensi rohaniah anak melalui pendidikan shalat ketika anak

${ }^{9}$ Muhammad Fadhil Al-Jamaly, Filsafat Pendidikan dalam al-Qur'an (Surabaya: Bina Ilmu, 1986), 25. 
usia tujuh (7) tahun dan memberikan peringatan keras mereka ketika sudah berusia sepuluh (10) tahun namun meninggalkannya, serta memisahkan ranjang antara anak laki-laki dan perempuan (HR. al-Tirmidzi). Dalam konteks hadits ini membiasakan dan mendidik kedisiplinan anak sejak usia dini menjadi penting dilakukan. Di samping itu, melatih anak agar potensi jasmaniahnya berkembang juga diisyaratkan agar orang tua mengajari anaknya (baik laki-laki maupun perempuan) berenang dan memanah (HR.al-Baihaqi). Dengan orientasi pendidikan yang demikian, diharapkan kedua aspek (jasmaniah-rohaniah) tersebut bisa berkembang secara beriringan

Dengan demikian, sesungguhnya optimalisasi potensi jasmani dan rohani anak didik baik laki-laki maupun perempuan, adalah dalam rangka mewujudkan perannya sebagai khalifah yang memiliki tugas untuk mengolah alam dengan menggunakan segenap daya dan potensi yang dimilikinya, sekaligus sebagai abid yang seluruh usaha dan aktivitasnya dilaksanakan dalam kerangka ibadah kepada Allah.

Manusia dengan segala potensinya, memiliki karakter individual yang berbeda-beda. Islam sangat menghargai kreativitas dan produktivitas (QS. 53: 3940), karena manusia adalah mahluk yang mampu berkreasi dan bertanggung jawab (QS.16: 93), mengingat pribadi manusia yang unik dan penuh potensi laten (QS.30:30) minat (Q. 18: 29) dan kemampuan (QS. 11: 3). Oleh karena itu, kebebasan dan keadilan dalam memperlakukannya, serta persamaan dalam memandang harkat dan martabatnya harus ditunjukkan oleh seorang pendidik. Isyarat al-Quran yang sangat menekankan bahwa penghargaan Tuhan terhadap 
seseorang bukan disebabkan karena laki-laki atau perempuan, etnis Jawa atau Madura dan sebagainya, tetapi karena karya positif yang telah dipersembahkan oleh orang tersebut kepada orang lain, sebagai perwujudan 'abid dan khalifah yang bertaqwa, di muka bumi ini (QS. 49: 13).

Untuk mewujudkan pribadi manusia yang harus dilatih dan dikembangkan fungsi khalifah dan abidnya itulah peran keluarga sebagai basis pertama pendidikan anak, akan sangat mempengaruhi dan membentuk perilaku anak. Role mode serta relasi ayah dan ibu, akan sangat membentuk pola pikir, sikap dan perilaku mereka. Untuk itulah, orang tua sebagai guru pertama dan utama dalam konteks pendidikan anak, berkewajiban memberikan dan menciptakan lingkungan pendidikan yang kondusif bagi tumbuh berkembangnya potensi anak secara positif. $^{10}$ Ayah yang berlaku kasar terhadap ibu, akan dengan mudah ditiru anaknya bahwa laki-laki memang harus berlaku kasar terhadap perempuan. Hal ini kelak akan berakibat pada pola pikir anak ketika menghadapi temannya yang perempuan, serta kelak ketika ia punya isteri. Inilah sesungguhnya yang diisyaratkan dalam hadits nabi: "setiap anak (laki-perempuan) lahir dalam keadaan fitrah, kedua orang tuanyalah yang membuatnya Yahudi, Nasrani maupun Majusi” (HR. Muslim).

Dengan demikian, laki-laki dan perempuan memiliki potensi by nature yang sama, yakni potensi ketuhanan (ruh Tuhan). Oleh karena itu, pembentukan kepribadian anak dalam konteks normativitas (sebagaimana disebutkan dalam alQur'an maupun al-hadits) maupun konteks historisitas (sebagaimana dicontohkan

\footnotetext{
${ }^{10}$ Muhammad. Awwad Jaudah, Mendidik Anak Secara Islam (Jakarta: Gema Insani Press, 1995), 37.
} 
oleh nabi) tidak pernah ada pembedaan. Demikian juga penghargaan Tuhan kepada keduanya, tidak didasarkan kepada jenis kelaminnya tetapi pada kadar ketaqwaan yang dicapainya (QS. Al-Hujurat: 13).

\section{PADU Sebagai Upaya "memerdekakan" Anak}

Manusia sebagai mahluk Tuhan yang bermartabat, memiliki multi predikat, yakni sebagai mahluk terbaik dan termulia, pemegang amanah, bertanggung jawab, memiliki hak pilih bebas, menyandang kelebihan sekaligus kelemahan, menyandang peran ganda serta menyimpan fitrah ber-Tuhan. Untuk merealisasikan predikatnya itu, Tuhan menyediakan sarana yang diperuntukkan manusia, dalam rangka mengemban tugas dan amanah sebagai khalifah (QS.2: 31, QS.38: 26). Beban dan tugas suci kekhalifahan manusia adalah memakmurkan bumi dan mensejahterakan hidup (QS. 11:61). Dengan demikian, ia memiliki tanggung jawab terhadap segala pilihan jalan hidupnya. Di sinilah manusia diuji, apakah ia mampu mendominasikan potensi konstruktif (taqwa) yang membawanya kepada rahmat Tuhan, atau sebaliknya mendominasikan potensi destruktifnya (fujur), yang mengantarkannya ke jalan kehidupan yang penuh la'nat.

Oleh karena itu, diperlukan maksimalisasi potensi dan fungsi pikir, dzikir dan kreativitas setiap manusia, yang berbasis pada nilai-nilai Ilahi. Adanya eksploitasi satu pihak terhadap pihak lain, berarti ada pengingkaran dan perampasan terhadap hak dasar setiap orang bahwa ia memiliki kebebasan dan kemerdekaan. Dengan demikian, pihak lemah yang tereskploitasi menjadi obyek yang kemanusiaannya "terpasung", baik oleh individu maupun oleh sistem, 
apakah itu sistem sosial, ekonomi, politik, dan budaya, yang menempatkan obyeknya pada posisi peripheral, marjinal dan jauh dari nilai-nilai kemanusiaan.

Manusia adalah mahluk Tuhan, yang dianugerahi kebebasan dan kemerdekaan. Kebebasan untuk patuh atau mengingkari-Nya (QS. 97: 7-8), kebebasan untuk bersyukur atau mengingkari nikmat-Nya (QS. 27: 40) dan seterusnya. Namun patut diingat, bahwa kebebasan yang diberikan Tuhan kepada manusia, menuntut konsekuensi-konsekuensi pertanggungjawaban, sebagai bentuk keadilan-Nya. Menempuh jalan kebaikan berarti surga, dan menempuh jalan kejahatan berarti neraka. Itulah keadilan Tuhan. Namun demikian, Tuhan memiliki rahmat tanpa batas, yang bisa diberikan kepada siapapun yang dikehendaki-Nya. Itulah kehendak mutlak Tuhan.

Untuk memilih jalan kebaikan, Tuhan telah memberikan piranti fitrah dan hati nurani. Dengan piranti itu, manusia akan mampu mendominaskan potensi kebaikannya. Karena pada diri manusia ada citra Tuhan, sebagaimana tersebut dalam teks hadits yang oleh para sufi dimaknai sebagai "Imagio Dei": "Allah menciptakan Adam berdasarkan gambar-Nya”. Dengan demikian, di dalam diri manusia, terdapat dimensi kemanusiaan (nasutiyah) dan dimensi ketuhanan (lahutiyah). Dimensi nasutiyah manusia adalah fisik dan jasmaninya yang membutuhkan makan, minum, berhubungan seksual dan kebutuhan biologis lainnya. Sedangkan dimensi lahutiyah-nya adalah sifat-sifat Tuhan yang harus diejawantahkan dalam kehidupannya, karena dalam diri manusia terdapat ruh Tuhan (QS.15:28-29), yang dengan demikian, sifat-sifat Tuhan inhern dengan eksistensi manusia di bumi ini. 
Kebebasan dan kemerdekaan manusia yang ditegakkan sejak semula, telah dikonsepsikan dalam lima hak dasar kemanusiaan (al-dharuriyat alkhamsah). Konsep inilah yang kemudian dipandang sebagai basis hak asasi manusia (HAM) dalam perspektif Islam. Kelima hak dasar dimaksud adalah: hak hidup (hifz al-hayat), hak beragama (hifz al-din), hak kepemilikan atas harta (hifz al-mal), hak akan kemerdekaan dan kreativitas berfikir (hifz al-'aql), dan hak untuk memelihara keturunan (hifz al-nasl).

Untuk menegakkan HAM, Tuhan telah membuat aturan main (role of the game). Semua kebebasan dan hak-hak yang dimiliki seseorang bukanlah kebebasan absolut dan tanpa batas. Di samping memiliki hak, manusia juga mempunyai kewajiban yang dibebankan Tuhan kepadanya, yakni patuh terhadap perintah dan larangan-Nya. Perintah-Nya adalah agar manusia berbuat baik dan tidak mengutamakan kepentingan diri sendiri (QS.59:9). Dengan demikian, kebebasan dalam Islam memiliki batasan-batasan.

Untuk menjaga hak hidup, Tuhan melarang manusia untuk saling membunuh tanpa hak. Jika seseorang merampas nyawa orang lain, maka hak hidupnya sendiri terganggu oleh perbuatan melanggar hak hidup orang lain. Hak hidupnya hilang karena perbuatannya itu (QS.2: 178 dan 179). Untuk menjaga agama, Tuhan melarang satu pihak melakukan pemaksaan terhadap pihak lain untuk memasuki agama tertentu. Untuk menjaga harta, Tuhan mengatur pencariannya, melarang pencurian dan mengatur distribusinya (tasharruf). Untuk menjaga kreativitas berfikir, Tuhan melarang manusia meminum khamr yang bisa merusak sistem jaringan dan fungsi otak. Menjaga keturunan diatur dengan 
perkawinan dan melarang perzinaan. Kelima hak dasar kemanusiaan ini, dimiliki secara given sebagai nikmat kodrati semua manusia, tanpa membedakan jenis kelamin, ras, etnis dan agama. Hakikat kemerdekaan berarti terpenuhinya semua hak dasar kemanusiaan tersebut.

Menikmati kemerdekaan juga berarti terasahnya potensi dan kualitas fisik dan kualitas psikis, yang meliputi asah bakat, kalbu, kecerdasan serta kemampuan berfikir logis, bertindak inovatif dan kreatif, etika pergaulan yang prima, solidaritas sosial yang tinggi, kemandirian dan disiplin tinggi dan sebagainya. Pendek kata, bagaimana agar semua orang secara bersama-sama bisa menumbuhkan tiga potensi yang dimiliki, yakni: potensi jasmani (al-quwwah aljasmaniyyah); potensi intelegensia (al-quwwat al-'aqliyah); dan potensi jiwa (alquwwat al-nafsiyah). Hakikat individu merdeka adalah individu yang ketiga potensinya ini teraktualisasikan, tidak terhambat, dan tidak terpasung oleh sistem kultur dan struktur apapun. ${ }^{11}$

Problem terberat bagi kemerdekaan adalah ketidakadilan, baik ketidakadilan kultural maupun struktural. Ketidakadilan kultural dalam konteks ini berbasis pada iman sosial (grand narrative) masyarakat terkait dengan interpetasi dan pemahaman keagamaannya. Namun yang lebih urgen, cara pandang ini bisa bermula pada teologi yang tidak tercerahkan, teologi "bisu" dan teologi awang-awang. Padahal sesungguhnya konsepsi tawhid meniscayakan semua manusia merdeka, bebas dari segala penghambaan kepada selain Tuhan. Dengan demikian, konsep tawhid seharusnya menjadikan setiap orang merdeka

\footnotetext{
${ }^{11}$ Syeikhul Hadi Permono, "Hak Asasi Manusia (HAM) dalam Perspektif Islam", dalam TOLERANSI: Jurnal Dialog Lintas Agama, Volume II, No. 3, Februari 2001, 129-139.
} 
dan tidak memiliki ketundukan kepada selain Tuhan. Tetapi, realitasnya ketundukan pada sesembahan dan tuhan-tuhan palsu (pseudo gods) masih banyak dipraktikkan orang di berbagai tempat.

Sedangkan ketidakadilan struktural, berbasis pada sistem yang tidak memberikan kesempatan kepada semua orang untuk mengekspresikan dirinya, Kondisi ini membuat masyarakat tidak memiliki ketundukan kritis, sebuah ketundukan yang tidak membawanya terbebaskan dari himpitan sosiopolitis, sehingga ekpresi dan aktualisasinya tersumbat. ${ }^{12}$ Karena itu, praktik hegemonik, eksploitatif dan superioritas, adalah paradoks dengan tawhid.

Konsep tawhid ini pulalah yang menjadi misi pertama dan utama Muhammad SAW sejak pertama berdakwah di Makkah. Tawaran teologis ini sesungguhnya mendobrak sistem teologi yang membuat masyarakat Makkah Jahili sangat feodalistis dan hirarkhial. Karena itu, hadits Nabi: "tidak ada keutamaan orang Arab atas orang non- Arab" (la fadla li 'arabiyyin 'ala 'ajamiyyin), yang dibacakan saat haji wada' sesaat sebelum beliau dipanggil Tuhan, sangat relevan hingga sekarang.

Konsepsi tawhid ini, membuat semua orang sama dan sejajar di "mata" Tuhan dan untuk bisa mencapai Tuhan (QS. 49: 13). Kedekatan kita kepada Tuhan bukan karena kita laki-laki atau perempuan, orang Arab atau non Arab, kulit putih atau kulit hitam, beragama Islam atau non-Islam dan seterusnya, tetapi karena prestasi kita yang berwujud ketaqwaan.

\footnotetext{
${ }^{12}$ Farid Esack, Al-Qur'an, Liberalisme dan Pluralisme (Bandung: Mizan, 2000), 53.
} 
Ketaqwaan yang memerdekakan dalam konteks ini, tidak dalam arti ketaqwaan pasif, tetapi ketaqwaan aktif yang membuat manusia yang menyandangnya menjadi kreatif. Untuk mengembangkan kreativitas itu, maka tidak satu pihakpun berhak menghalangi pihak lain. Karena hal ini berlawanan dengan konsep tawhid yang menjadi basis hak-hak dasar kemanusiaan yang terangkum dalam konsep al-dharuriyat al-khamsah.

Dengan mengacu pada maqashid al-syari'ah tersebut, berarti setiap orang berhak secara penuh atas kebebasan dan kemerdekaan. Harapan kita, semoga upaya-upaya pencerahan untuk membawa manusia dari kegelapan ke jalan terang, dari kebiadaban ke keadaban, dari hegemoni ke kesejajaran, dari eksploitasi ke kebebasan, dan dari ketertindasan menuju kemerdekaan, tidak hanya menjadi kamuflase akademik belaka. Semoga, amin.

\section{E. Catatan Akhir}

Pada umunya perempuan yang berperan sebagai ibu bagi anak-anaknya, memiliki potensi besar untuk lebih mandiri. Peran sentralnya sebagai salah satu tokoh kunci dalam proses pendidik yang pertama dan utama bagi anak-anaknya, telah membangun jiwa perempuan sebagai pribadi yang tangguh. Bagaimana tidak, di sela-sela kesibukannya mengurus rumah tangga bersama suaminya, ia harus memberikan perhatian ekstra kepada anak-anaknya, bahkan ia juga turut berpartisipasi dalam upaya meng-cover kebutuhan ekonomi keluarga. Dalam konteks ini, peran perempuan sebagai ibu bukanlah peran tunggal, namun peran berganda dan bahkan ber-lapis-lapis. Namun demikian, dengan segala keterbatasannya, ia mampu menyelesaikan "tugas-tugas" itu dengan penuh 
komitmen dan tanggung jawab yang tinggi, baik secara kemanusiaan maupun ketuhanan. Semoga peran-peran "tradisional" perempuan tersebut, semakin diimbangi dengan pengertian dan pemahaman pihak laki-laki (suami/ayah), untuk tergerak hatinya memikliki rasa tanggung jawab yang sama dalam menumbuhkembangkan potensi anak-anak. Sehingga mereka menjadi generasi penerus yang berkualitas, hidup dalam alam kemerdekaan, kesetaraan dan keadilan sosial yang membebaskannya dari berbagai bentuk penindasan dan kedzaliman, baik yang dilakukan oleh masyarakat maupun oleh para orang tua mereka sendiri.

Wa Allahu a'lam bi al-shawab. 


\section{DAFTAR PUSTAKA}

Al-Abrasyi, M. Athiyah. Dasar-dasar Pokok Pendidikan Islam. Jakarta: Bulan Bintang, 1970.

Al-Jamaly, Muhammad Fadhil. Filsafat Pendidikan dalam al-Qur'an. Surabaya: Bina Ilmu, 1986

Arifin, M. Filsafat Pendidikan Islam. Jakarta: Bumi Aksara, 2000

Awwad, Jaudah Muhammad. Mendidik Anak Secara Islam. Jakarta: Gema Insani Press, 1995.

Depag RI. Al-Qur'an dan Terjemahnya. Diterbitlan atas kerjasama Depag RIKomplek Percetakan al-Qur'an Raja Fahd, 1412 H.

Jalaluddin dan Said, Usman. Filsafat Pendidikan Islam. Jakarta: Rajagrafindo Persada, 1994

Langgulung, Hasan. Beberapa Pemikiran tentang Pendidikan Islam.bandung: AlMaarif, 1980

Muhaimin dan Mudjib, Abdul. Pemikiran Pendidikan Islam: kjaian Filosofik dan Kerangka Dasar Operasioanalisasinya. Bandung: Trigenda Karya, 1993.

Nata, Abuddin. Filafat Pendidikan Islam. Jakarta; Logos, 1997

Permono, Syeikhul Hadi. "Hak Asasi Manusia (HAM) dalam Perspektif Islam", dalam TOLERANSI: Jurnal Dialog Lintas Agama, Volume II, No. 3, Februari 2001.

Sadali, A, dkk. Islam untuk Disiplin Ilmu Pendidikan. Jakarta: Bulan Bintang, 1987.

Zainuddin, dkk. Seluk-beluk Pendidikan dari al-Ghazali. Jakarta; Bumi Aksara, 1991. 